\title{
A Literature Review: The Impact of COVID-19 Pandemic on Somaliland Economy
}

\author{
Abdiaziz Harun Mohamed \\ Online Learning Platform, Department of Business and Economics, Tiigsi Technology Academy, Hargeisa, Somaliland \\ Email: harun3099@gmail.com
}

How to cite this paper: Mohamed, A. H. (2021). A Literature Review: The Impact of COVID-19 Pandemic on Somaliland Economy. Open Journal of Social Sciences, 9, 54-64. https://doi.org/10.4236/jss.2021.92004

Received: January 5, 2021

Accepted: February 4, 2021

Published: February 7, 2021

Copyright (C) 2021 by author(s) and Scientific Research Publishing Inc. This work is licensed under the Creative Commons Attribution International License (CC BY 4.0).

http://creativecommons.org/licenses/by/4.0/ (c) (i) Open Access

\begin{abstract}
COVID-19 pandemic has brought difficult situations for citizens of nations across the world. The impact however, may be more severe for others in the Third World Countries, who are in desperate situations and whose conditions may well further deteriorate if not put into considerations. While this pandemic affects different dimensions of life and society in general, this paper examines the impact of the outbreak COVID-19 pandemic on Somaliland Economy and analyzes the need for mitigation measures of this pandemic. The research methodology of this paper reviews secondary data which were collected through various magazines, articles, newspapers and published journals. The study focuses on descriptive research design and the sample design selected for this study which was illustrative. This study observed that COVID-19 is affecting the Somaliland economy through loss of jobs and other incomes, gradual recession and deterioration of public financial and private business sectors of the nation. The study discovers that for the recovery of the economy, certain mitigation measures and policy interventions must be administered, which includes health and social protection, fiscal policy and financial, industrial and trade policies. Therefore, the expected outcomes from administration of the policy instruments would be reduction in human suffering and the enhancement of the recovery of the economy from bankruptcy and recession.
\end{abstract}

\section{Keywords}

Impact, Economy, Pandemic, COVID-19, Somaliland

\section{Introduction}

An ongoing outbreak of pneumonia associated with a novel coronavirus, severe 
acute respiratory syndrome (SARS) coronavirus 2, was reported in Wuhan, $\mathrm{Hu}$ bei Province, China in December 2019, in the following weeks, infections spread across China and other countries around the world, resulting in a pandemic ( $\mathrm{Zu}$ et al., 2020). COVID-19 is a large group of viruses that creates illness. It ranges from the common cold to more severe diseases like Severe Acute Respiratory Syndrome (Shubhi \& Archna, 2020). The disease, currently there is no pharmaceutical treatment (Hevia \& Neumeyer, 2020). COVID-19 is having major consequences on the world economy, and experts have predicted that the virus will lower global gross domestic product growth by one-half a percentage point for 2020 from $2.9 \%$ to $2.4 \%$ (Gupta et al., 2020).

The economic consequences of the pandemic have not fallen with equal severity on all shoulders. Existing vulnerabilities have not been exposed, and inequalities entrenched (ILO \& OECD, 2020). Humanity will never forget December 2019 when the strange virus emerged. Since then, it threatens to become one of the most difficult tests faced by humanity in modern history with huge potentiality to take lives, overwhelm health systems and trigger lasting socio-economic change (Anthony, 2020). The IMF Report in 2020 observes that in the face of COVID-19 pandemic, the global economy faces its worst downturn since the great depression. Following Oxfam International in her 2020 report warned that half a billion people could be pushed into poverty as a result of the COVID-19 Pandemic (Anthony, 2020).

Somaliland reported its first two cases of COVID-19 on 31st March, 2020, currently in December, 2020, there are 1311 cases, 1249 individuals recovered and a total number of 43 deaths (Somaliland COVID-19, 2020). Prior to the confirmation of these cases, the government had already established COVID-19 task force, which has introduced travel restrictions and social distancing measures (Rius \& Diallo, 2020). Somaliland is a Sub-Saharan country located in the Horn of Africa, sharing boundaries with the Gulf of Aden in the North, Somalia in the east, the Federal Republic of Ethiopia in the southwest, and Djibouti in the Northwest. Somaliland unilaterally declared independence from Somalia in 1991; although internationally unrecognized, Somaliland has been self-governing ever since that declaration (Herring et al., 2020).

In Somaliland, imports duties contribute around $80 \%$ of the total revenue for the government while only $20 \%$ come from Inland Revenue (Bank of Somaliland, 2020). Somaliland's economic production and trade are dominated by livestock production. As of the poorest nations in the world, its poverty rates are higher and human development indicators are lower than other least developed countries in the region (Ministry of Planning \& National Development, 2017). The economy of Somaliland is an open and it trades with the rest of the world (IMF, 2020). The major sources of economic growth for Somaliland are Remittances funds from the Diaspora in Western Europe, North America and the Gulf countries (Bank of Somaliland, 2020).

Around $40 \%$ of households in rural and urban areas do not have any eco- 
nomically active individuals aged 15 to 54, these households are also more like to receive remittances (MoNPD, 2017). However, the increasing spread of the COVID-19 across countries has prompted many governments including Somaliland to introduce unpresented measures to contain the pandemic. These measures have led to many businesses being shut down temporarily, widespread restrictions on travel and mobility, financial market turmoil such as disruption of remittance channels (Bank of Somaliland, 2020).

The structure of this study was organized as follows. Section two is about the problem statement, section three and four are the objectives and methodology and procedure of the paper, section five consists of review of related literature to the pandemic, section six and seven gives concluding remarks and policy recommendations for mitigating the COVID-19 pandemic.

\subsection{Problem Statement}

COVID-19 is spreading human suffering worldwide; that is what we should all be focused on. But we are not doctors, we are economists and COVID-19 is most definitely spreading economic suffering worldwide (Baldwin et al., 2020). However, the government of Somaliland has implemented a partial lockdown and this largely affected public offices including Schools and Universities as well as office based businesses. The COVID-19 also affected Somaliland's major economic sectors including aviation, hospitality and domestic transport (Musa, 2020).

After the outbreak of COVID-19, a significant reduction of the remittance inflow to the nation is expected to decline due to the global lockdowns that may bring the loss of jobs for the diaspora community and the closure of financial institutions such as banks and money transfer operators (Bank of Somaliland, 2020). Social distancing, self-isolation and travel restrictions forced Somaliland a decrease in the workforce across all economic sectors and caused many jobs to be lost. Schools have closed down, and the need of manufactured products has decreased. The food supply has also seen a great demand (Duale, 2020).

\subsection{Objectives of Research}

- To examine the impact of pandemic COVID-19 on Somaliland economy.

- To analyze the need for mitigation measures of this pandemic COVID-19.

\section{Research Methods}

This part of the research furnishes the research methodology was used in this study. This study considers December 2020 to January 2021 as its study period. The review of the research was used secondary data. The data was collected through various magazines, articles, published access journals, newspapers and public and government portals (websites) for the study. This study focuses on descriptive research design. The sample design chooses for this study was illustrative. 


\section{Literature Review}

\subsection{Impact of COVID-19 on Businesses}

In Somaliland, the COVID-19 outbreak has forced many businesses and stores to close, leading to an unpresented disruption of commerce in most industry sectors. Retailers and brands face many short-term challenges, such as those related to health and safety, the supply chain, the workforce, cash flow, consumer demand, sales and marketing (Donthu \& Gustafsson, 2020). Private electricity Companies increased the cost of bills due to dependent on fuel imports from foreign countries. Therefore, price changes in all services have importance consequences for all Somaliland's business sectors (Rius \& Diallo, 2020).

In addition to its impact on public health, coronavirus disease 2019 has caused a major economic shock. The pandemic had already caused massive dislocation among small businesses just several weeks after its onset, approximately $25 \%$ of businesses had temporarily closed and nearly all of these closures were due to COVID-19 (Bartik et al., 2020). Business owners have been shocked with challenges of their businesses to include irregular running of businesses, work methods and possible financial constraint on Companies with uncertain of the future (Stephen, 2020).

The COVID-19 is likely to cause bankruptcy for many well-known brands in many industries as consumers stay at home and economies and shut down (McKee \& Tucker, 2020). This is not only having consequences for the economy; all of society is affected, which has led to dramatic changes in how businesses act and consumers behave (Donthu \& Gustafsson, 2020). Most major industries faced large drops in the number of business owners with the only exception being agriculture. Construction, restaurants, hotels \& transportation all faced large declines in the number of business owners due to COVID-19 (Fairlie, 2020).

\subsection{Impact of COVID-19 on International Trade \& Export}

The COVID-19 pandemic has pushed the world into recession. For 2020 it was the worse than the global economic crisis. The economic damage is mounting across all countries, tracking the sharp rise in new infections and containment measures in place (IMF, 2020). As result of the pandemic, the global economy is projected to contract sharply by $3 \%$ in 2020 much worse than during 2008-09 financial crisis (Bank of Somaliland, 2020). The tourism sector alone faces an output decrease as high as 70\% (OECD, 2020).

COVID-19 has a growing impact on the economy of Somaliland, though the current impact is more on short-term, the medium and long-term of the impact is still unknown. These short term economic impacts can translate into reductions in long-term growth and difficult to recover (Bank of Somaliland, 2020). Somaliland imports are decreased due to COVID-19 and this has fiscal and unemployment adverse implications, because import duties contribute around $80 \%$ of the total revenue for the government while only $20 \%$ comes from Inland Revenue (Bank of Somaliland, 2020). 
The Somaliland's export to other countries which is mainly livestock and its byproducts are expected to decline significantly due to disruptions of world supply chains and quarantine measures spread across the global. Total export value of 2019 was $\$ 212$ million, which is less than the total import value of the same year a deficit of $\$ 361$ million (IMF, 2020). Using the current IMF prediction, the volume of export of emerging and developing countries is predicted to decline $-9.6 \%$ which implies that the total export value of Somaliland will decline to 191.4 million, when the base year is 2019 total export value (Bank of Somaliland, 2020).

\subsection{Impact of COVID-19 on Remittance Flows}

Over the years, the Somali culture of trust has created a well-functioning money transfer business which has allowed Somali-lander's in Diaspora to send money back home. In the old days migrants from Somaliland used to remit money to their relatives either via international bank transfers (Bank of Somaliland, 2020). The volume of remittances received in Somaliland in 2018 was $\$ 1.4$ billion which is equivalent to $51 \%$ of GDP. This makes one of the most remittance-dependent economies in the World (Ministry of Planning \& National Development, 2017).

Annual remittances are estimated at $\$ 1$ billion approximately 38\% of Somaliland's GDP. The indirect impact of COVID-19 on Somaliland as a result of the virus' effects on importing countries and countries of residence to the Somali diaspora is yet unknown (Rius \& Diallo, 2020). Around $40 \%$ of households in rural and urban areas do not have any economically active individuals aged 15 to 54. These households are also more likely to receive remittances (MoNPD, 2017). Households without any economically active adults are around three times as likely to receive remittances in both urban and rural areas as shown below in Figure 1.

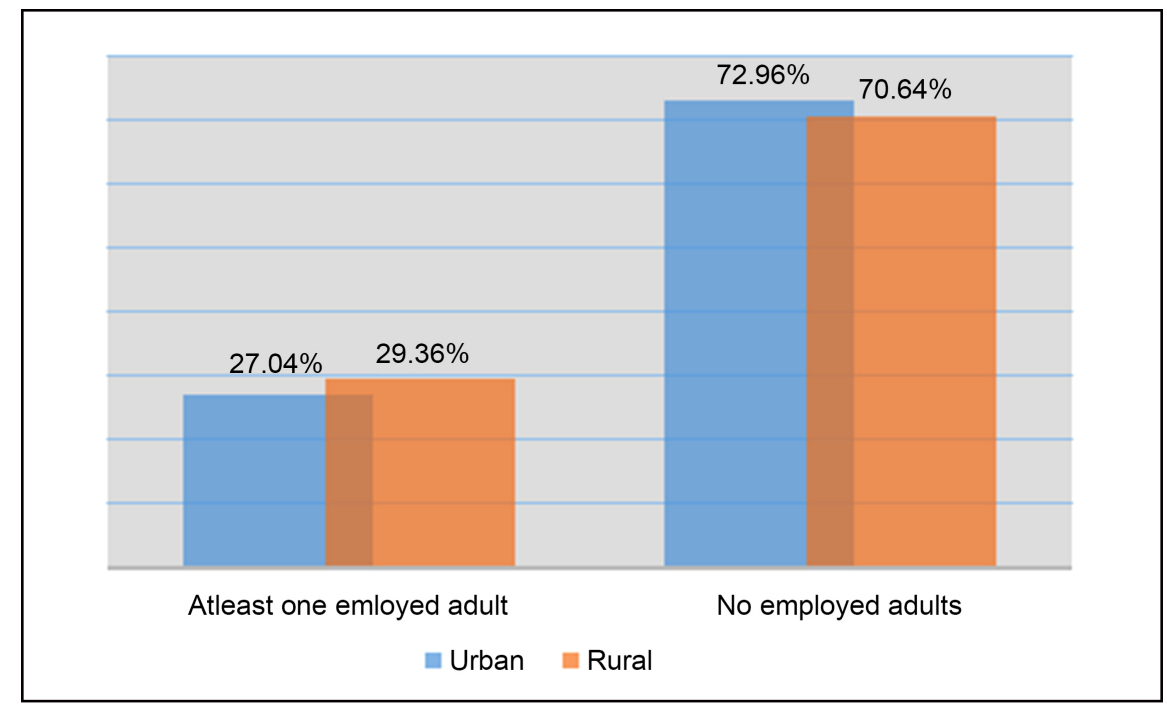

Source: Reproduced from World Bank (2015) and based on SLSH (2013)

Figure 1. Households with \& without employed adults receiving remittances. 
A fall in remittance levels is already being noticed and is of concern to local people in Hargeisa-Somaliland due to COVID-19 (Musa, 2020). There are different reasons for this including the reluctance of senders to physically visit shops and outlets, which is a common means of transferring money as well as the difficulty money transfer operators face in gathering physical cash from agents in diaspora settings and moving that cash to their headquarters in Dubai, due to flight restrictions (Musa, 2020). Remittances are falling as a result of the pandemic. Countries, where remittances are sent, are on lock down or under restrictions. Other factors affecting this may include migrants having insufficient funds as a result of employment loss; unavailability of services to cash in or cash in the money remittances cash based firms (Bank of Somaliland, 2020).

\subsection{Impact of COVID-19 on Employment}

According to International Labor Organizations, 2020, the crisis has already transformed into an economic and labor market shock, impacting not only supply but demand consumption and investment (ILO \& OECD, 2020). However, the government of Somaliland has imposed partial restrictions and lock downs on vast majority of businesses and economic activities in the nation, pushing thousands of people to lost their jobs and increase the unemployment rate for example the social distancing and movement restriction measures brought to close both public and private schools, sports and entertainment centers (Bank of Somaliland, 2020). Providers of private and public employment services have been placed under a severe stress test as demand for their services sky-rocketed in the first few months of the crisis while their capacity was severely constrained by the need to curtail face-to-face contact with job seekers (ILO \& OECD, 2020).

In urban areas, most working adults are found in the services sector $(67.8 \%)$ as well as wage employees (71.4\%). However, working adults in rural areas are divided almost equally between services (48.9\%) and agriculture and livestock activities (40.4\%). Wage employees in rural areas are mainly found in services with less than $5 \%$ working in agriculture and livestock activities. Services include shop assistants, demonstrators, hairdressers, barbers, beauticians, housekeepers, cookers and other catering services workers and extra (MoNPD, 2017). Table 1 shows how employees scattered through different sectors.

Table 1. Primary sector of work.

\begin{tabular}{ccccc}
\hline & \multicolumn{2}{c}{ Adults (\%) } & \multicolumn{2}{c}{ Wage Employees (\%) } \\
\cline { 2 - 5 } & Rural & Urban & Rural & Urban \\
\hline Agriculture and livestock & 40.4 & 5.4 & 5.1 & 3.7 \\
Mining and Extraction & 0.5 & 0.2 & 0.4 & 0.2 \\
Manufacturing & 1.4 & 4.7 & 1.4 & 4.3 \\
Construction & 2.8 & 8.4 & 8.0 & 11.6 \\
Services & 48.9 & 67.8 & 67.3 & 71.4 \\
\hline
\end{tabular}

Source: Reproduced from Word Bank (2015) and based on SLHS (2013). 
The impact of COVID-19 pandemic will be felt not just on the national economy but on the household economy of local people. It is devastating impact is already unfolding in Somaliland. Daily wage earners have been badly hit; many have nothing to live on now and are unable to buy food for their families. Hunger, malnutrition and other problems that have always plagued Somaliland are poised to intensify as a result of the lockdown (Duale, 2020). On the other hand, people are unable to stay at homes without their work for their survival; thus they are concerned much more about their job rather than COVID-19 pandemic (Duale, 2020). While some businesses have found ways to keep going during COVID-19 response, others are having a harder time. Authorities have urged people to halt the spread of the outbreak virus and this has had knock-on effect on Somaliland's hospitality sector (UNSOM, 2020).

\subsection{Impact of Fiscal Measures (Policy)}

COVID-19 outbreak has disrupted economic activities across the globe. Not only workers and businesses affected, but also the fiscal capacity of governments has been affected by the virus (Bank of Somaliland, 2020). Government spending is low compared with Somaliland's GDP and dependent on import flows. The 2020 budget includes expenditures of $\$ 245$ million (approximately $10 \%$ of GDP) at current exchange rates, $95 \%$ of total revenue is domestically sources and more than $50 \%$ of that comes from taxes on imported goods (Rius \& Diallo, 2020). IMF predicts that the import volume of developing countries is expected to decline $-8.2 \%$ in 2020 , while expert volume of the same countries is projected to decline - 9.6\% (IMF, 2020).

The government of Somaliland is currently unable to access international bond markets and so is currently unable to utilize its strong fiscal position to attract finance to invest in development due to livestock ban and the impact of COVID-19 pandemic (MoNPD, 2017). If the uncertainty of the pandemic continues, there will be a significant reduction of trade volume both imports and exports (Bank of Somaliland, 2020). This will reduce revenues from the trade activities particularly imports, the greatest source of revenue in Somaliland (MoNPD, 2017). Although the policies currently being implemented are likely to have substantial impacts on the level and composition of expenditure, there has been no official communication on a revised budget as yet (Rius \& Diallo, 2020).

\section{Conclusion}

COVID-19 is expected to have a severe impact on economy, enterprises and industries on all sizes, resulting in reduced incomes for vulnerable macro and micro-economies and the risk of job losses and lost incomes for thousands of low-paid workers. The increasing spread of COVID-19 across countries has prompted many governments including Somaliland to introduce unpresented measures to contain the pandemic. However, the government of has imposed partial restrictions on vast majority of businesses and economic activities in the 
country as a result of banning social gathering and closed all Schools, Universities, Sports Centers and Kat tea shops.

Somaliland imports are decreased due to pandemic and this has fiscal and unemployment adverse implications. After the outbreak of COVID-19, a significant reduction of remittance inflow to the nation has declined due to the Global lockdowns that brought the loss of jobs for the Diaspora community and the closure of financial institutions such as banks and monetary transfer operators. Social distancing, self-isolation and travel restrictions forced a decrease in the workforce across all economic sectors and caused many jobs to be lost. Schools and Travel and Tour Agencies have closed and the need of commodities and manufactured products has decreased.

The food supply has also seen a great demand due to panic-buying and stockpiling of food items. Partial restrictions and the closure of some business sectors forced thousands of people to lost their jobs and increase the unemployment rate, for example, the social distancing and movement of restrictions measures brought to close both public and private schools, sports and entertainment centers. Providers of private and public employment services have been placed under a severe stress test as demand for their services sky-rocketed in the first few months of the crisis while their capacity was severely constrained by the need to curtail face-to-face contact with job seekers.

Daily wage earners have been badly hit; many have nothing to live on now and are unable to buy food for their families. On the other hand, people are unable to stay at home without their work for their survival, thus they are concerned much more about their job rather COVID-19. The government of Somaliland is currently unable to access internal bond markets and so is unable to utilize its strong fiscal position to attract finance to invest in development due to livestock and the impact of pandemic. This is also reduced the government revenues from the trade activities particularly imports, which is the greatest source of revenue in Somaliland.

The consequence of the COVID-19 pandemic on Somaliland's economy is one that the country will have to grapple with for years to come. The policy response will go a long way in determining how long it would last. If it is late, weak or uncoordinated, the devastating consequences would last longer. However, if the response is prompt, effective, strong and coordinated, it would be less devastating. This is late time the government to reset everything as the world has become standstill for a few months due to the outbreak of COVID-19. Somaliland National COVID-19 Task force does not plan, rethink, redesign, and restructure everything to combat the pandemic and protect its citizens and micro and macro-economic sectors.

\section{Recommendations}

There is an urgent need for Somaliland to form a combination of monetary, fiscal and financial markets measures to help economies and businesses to cope 
with this spread of virus and crisis environment. For framing appropriate action plans and policy, it is significant to know the specific issues that businesses and the public in general are facing recently. However, this paper suggests the following recommendations:

1) As a way forward, the immediate focus on the nation should be on measures to contain the spread of the disease COVID-19 and to treat the individuals infected. The ability to stop its spread and treat the sick will have very positive consequences on the economy.

2) The time has come to focus on developing the local economy with the hope of having a nation that is dependent on local goods rather than over-dependence on importation. At this time of COVID-19, Somaliland should learn lessons and start producing cash crops, finished goods like toothpick, face masks, ventilators and extra for a locally.

3) To save the economy, companies and other industries relieving or laying off workers of their job is not the solution to the problem, holistically viewed it creates another problem. However, it is important to emphasize the importance of employers' loyalty and there should be more of negotiation than relieving employees of their jobs.

4) As we all know, there are large number of people who lose their jobs in many sectors like the retail, hospitality, travel and tourism, construction industry and transportation Companies, etc. so the government is required to provide incentives for short or long term solutions such as tax payment extensions, subsidies, loans or cash funding and other financial assistances to employers to keep workers until COVID-19 problem.

5) There is a need to provide relaxation in the factory compliances to enable the industries to continue operation even in few laborers over longer work keeping in mind the healthier and save environment. Social distancing is followed in this and can bring a positive outcome. If required health concerns and lockdown decisions must be followed strictly.

6) There is a need to raise expenditure on public health to maintain adequate supplies to manage the problem of COVID-19; medicines, medical kits for the medical professionals, masks, gloves, more health clinics, more hospitals, etc.

7) There is a need to provide income support to SMEs, Tourism, Hospitality, Education and low-income households. Formers should be supported by giving Minimum Support Prices for their harvests. There is a need to provide relief programs to those farmers who have lost their output due to this pandemic, unseasonal rains and weather harshness.

8) The government of Somaliland must implement certain measures to contain the rapid spread of the COVID-19 disease including full closure of borders, in-bound traveler quarantine, passenger limitations, etc.

9) The Central Bank of Somaliland must issue directives to local Public and Private Banks encouraging them to ease credit access and lending to Small and Medium sized businesses and low income individuals by relaxing stringent cre- 
dit conditions, policies, procedures and processes.

10) A large inflow of money may bring severe liquidity risk to the stability of the financial system and enhance the economy of the nation. Therefore, The Central Bank of Somaliland must critically watch and control the outward flow of foreign currency funds from the country to abroad.

\section{Conflicts of Interest}

The author declares no conflicts of interest regarding the publication of this paper.

\section{References}

Anthony, K. I. (2020). COVID19 and the Economy African Perspective. Journal of African Studies and Sustainable Development, 3, 1-8.

Baldwin, R. E., Weder, B., \& Centre for Economic Policy Research (2020). Economics in the Time of COVID-19 (Vol. 1). London: Centre for Economic Policy Research.

Bank of Somaliland (2020). Impact of COVID-19 on Somaliland Economy. Central Bank Magazine, 1, 1-20.

Bartik, A. W., Bertrand, M., Cullen, Z., Glaeser, E. L., Luca, M., \& Stanton, C. (2020). The Impact of COVID-19 on Small Business Outcomes and Expectations. Academic Journal, 117, 17656-17666. https://doi.org/10.1073/pnas.2006991117

Donthu, N., \& Gustafsson, A. (2020). Effects of COVID-19 on Business and Research. Journal of Business Research, 117, 284-289.

https://doi.org/10.1016/j.jbusres.2020.06.008

Duale, A. (2020). Somaliland and COVID-19: Government Response and Socio-Economic Impact. United International University. https://www.horndiplomat.com/2020/06/15/somaliland-and-covid-19-government-res ponse-and-socio-economic-impact

Fairlie, R. W. (2020). The Impact of COVID-19 on Small Business Owners (pp. 1-23). NBER Working Paper Series 27309, Cambridge, MA: National Bureau of Economic Research.

Gupta, M., Abdelmaksoud, A., Jafferany, M., Lotti, T., Sadoughifar, R., \& Goldust, M. (2020). COVID-19 and Economy. Dermatologic Therapy, 33, 1-2.

Herring, E., Campbell, P., Elmi, M., Ismail, L., Jama, J., McNeill, S., Rubac, A., Saed Ali, A., Saeed, A., \& Yusuf, M. (2020). COVID-19 and Sustainable Development in Somalia/Somaliland. Global Security: Health, Science and Policy, 5, 93-110. https://doi.org/10.1080/23779497.2020.1824584

Hevia, C., \& Neumeyer, A. (2020). A Conceptual Framework for Analyzing the Economic Impact of COVID-19 and Its Policy Implications. http://www.latinamerica.undp.org

ILO \& OECD (2020). The Impact of the COVID-19 Pandemic on Jobs and Incomes in G20 Economies. ILO-OECD Paper Prepared at the Request of G20 Leaders, Saudi Arabia's G20 Presidency, G20 Saudi Arabia, 1-46.

ILO, \& OECD. (2020). The Impact of the COVID-19 Pandemic on Jobs and Incomes in G20 Economies.

IMF (2020). Working Closely with the Other International Financial Institutions to Provide a Strong Coordinated Response. Ministerial Call on the Coronavirus Emergency. Statement of G20. International Monetary Fund. 
McKee, M., \& Tucker, D. (2020). If the World Fails to Protect the Economy, COVID-19 Will Damage Health Not Just Now But Also in the Future. Nature Medicine, 26, 640-642. https://doi.org/10.1038/s41591-020-0863-y

Ministry of Planning \& National Development (2017). Somaliland National Development Plan II Final (pp. 1-340). Somaliland National Development Plan Strategy, 2 (MoNPD).

Musa, N. M. (2020). Somaliland and COVID-19: Emerging Issues and Economic Impact. London School of Economics.

https://blogs.lse.ac.uk/crp/2020/04/23/somaliland-and-covid-19-emerging-issues-and-e conomic-impact

OECD (2020). New Organization for Economic Cooperation and Development Outlook on Global Economy, and Evaluating the Initial Impact of COVID-19 Containment Measures on Economic Activity.

Rius, A., \& Diallo, M. S. (2020). Economic Impacts of and Policy Responses to the Coronavirus Pandemic: Early Evidence from Somaliland.

Shubhi, \& Archna (2020). COVID-19 and Its Impact on Indian Economy. International Journal of Trade and Commerce, 9, 1-2.

Somaliland COVID-19 (2020). Ministry of Health Development. Coronavirus-19 Updates. Ministry News for COVID-19 Decisions. Health Messages and Call Emergency. Africa and World Updates. https://somalilandcovid19.com

Stephen (2020). COVID-19 Employment and Lockdown: Implications and Recommendations.

UNSOM (2020). Joint Statement on COVID-19. United Nations of Political and Peace building Affairs. United Nations Assistance Mission in Somalia. https://unsom.unmissions.org/joint-statement-covid-19

World Bank (2020). Impact of COVID-19: Policies to Manage the Crisis and Strengthen Economic Recovery, Open Knowledge Repository. Somalia Economic Update Report. https://openknowledge.worldbank.org/handle/10986/34239

Zu, Z. Y., Di Jiang, M., Xu, P. P., Chen, W., Ni, Q. Q., Lu, G. M., \& Zhang, L. J. (2020). Coronavirus Disease 2019 (COVID-19): A Perspective from China. Radiology, 296, E15-E25. https://doi.org/10.1148/radiol.2020200490 